\title{
TECHNIQUES EVALUATION - COMLEXITY CONDITION IN TECHNICAL SUBJECTS TEACHING
}

\section{Jiří KROPÁČ st. - Jiř́ KROPÁČ ml. - Jitka PLISCHKE}

\begin{abstract}
The encorporation of techniques evaluation into the technical subjects teaching represents the complexity condition for their teaching. The term 'complexity' represents completeness, which means that through educational results the education fulfills its role in full. The complexity is associated with the integration of educational results. The article elaborates main approaches to the encorporation of techniques evaluation into the technical subjects teaching. The problematics is demonstrated on the example of the instruction aimed at the municipal waste combustion.
\end{abstract}

Key words: complexity condition for teaching, technical subjects, techniques evaluation, municipal waste combustion.

\section{HODNOCENÍ TECHNIKY - PŘEDPOKLAD KOMPLEXNOSTI VÝUKY TECHNICKÝCH PŘEDMĚTŮ}

Resumé: Začlenění hodnocení techniky do výuky technických předmètů je podmínkou komplexnosti výuky. Označení komplexnost vyjadřuje úplnost, tedy to, že vzdělávacími výsledky naplňuje výuka ,své posláni" v plném rozsahu. Komplexnost souvisi s integraci výsledkì vzdělávání. Ve stati jsou rozpracovány hlavní př̀stupy kzačlenění hodnocení techniky do výuky technických předmètů. Problematika je demonstrována na př́kladu výuky zaměřené na spalování komunálního odpadu.

Klíčová slova: podmínka komplexnosti výuky, technické předměty, hodnocení techniky, spalování komunálního odpadu.

\section{1 Úvod}

Komplexnost jako vlastnost výuky i výsledků výuky vyjadřuje úplnost, především to, že vzdělávacími výsledky naplňuje daná výuka očekávané záměry v plném rozsahu. Související pojem integrace výsledků vzdělávání je chápán jako „scelení“, propojení vzdělávacích výsledků a činností k tomu směřujících.

Komplexnost výuky je běžně vnímána jako úplnost obsahu zhlediska zastoupení věcných oblastí, tohoto způsobu chápání si povšimneme stručně v části 2 této stati. Nelze ale zapomínat na další hlediska komplexnosti, zejména hledisko nezbytnosti odpovídajícího zastoupení postupů a způsobů technického myšlení ve výuce $(1, \mathrm{~s}$. 22-33). Nezbytnou, trvalou součástí technického myšlení je hodnocení založené na kritickém myšlení a vedoucí k zodpovědnému rozhodování. Toto hledisko komplexnosti výuky může být do značné míry považováno za vertikální integraci, znamenající jak integraci teorie a praxe, tak integraci znalostí, dovedností, vztahů a postojů s hodnocením techniky souvisejících. $\mathrm{K}$ rozvíjení schopnosti zodpovědně hodnotit a rozhodovat o využití techniky na základě podložených informací je efektivní využít témata nabízející „svou rozpornosti““ dostatek př́ležitostí pro hodnocení a obhajobu svých stanovisek žákem. V této stati se budeme zabývat př́stupy k organickému začlenění hodnocení techniky do výuky ,jiných technických témat“" a to na prríkladu hodnocení ve výuce o spalování komunálního odpadu.

Zdůrazníme ještě, že není cílem učitele sjednotit názory a postoje žáků, jde o výuku vyžadující jeho cit i takt. Náročnost této výuky odpovídá postavení kategorie cílů ,hodnotit“ v Bloomově taxonomii cílů výuky (2).

\section{2 Úplnost zastoupení techniky a technologií v obsahu výuky}

Stručný název lze podrobněji formulovat jako komplexnost či úplnost výuky o technice a technologiích (dále jen o technice) dosahovaná zastoupením relevantních oblastí techniky odpovídajícími tématy výuky. Způsob volby těchto témat se liší u všeobecně a u odborně zaměřených technických předmětů.

U odborných technických předmětů je komplexnost zastoupení techniky v obsahu výuky a také $\mathrm{v}$ tématech učiva dosahována, pokud na základě jejich absolvování žák dobře umí všechny odborné činnosti, které po něm v profesi mohou být žádány. 
Dosahování komplexnosti zastoupení techniky v obsahu výuky všeobecně zaměřených technických předmětů je z podstaty obtížné, nemůže být dosažena „V plném rozsahu“. Za této situace je výběr témat předurčen mírou potřebnosti výsledků vzdělávání při řešení u žáka očekávaných situací spojených s technikou, dále zájmy žáků, rozvíjením duševních schopností a vychovanosti žáků i možnostmi integrace dosahovaných vzdělávacích výsledků (3). Požadavek komplexnosti z uvedeného hlediska je zde podle našeho názoru nejvhodněji dosahován, jsou-li vymezeny „trrídy“ technických objektů, materiálů, procesů, pokrývající svým rozsahem celou ,požadovanou“ oblast techniky, podrobněji (4). Tyto třídy jsou ve výuce jednoduše řečeno reprezentovány vhodně zvoleným tématem, jde o využití exemplarismu. Pro vymezení tříd lze např. využít prací $H$. Wolffgramma (5), (6), které přinesly systemizaci technologických činností do vyšších skupin, jiný způsob vymezení tříd vhodný pro obecně technické předměty, podle etap „vzniku a života techniky“, uvádějí W. Furmanek a W. Walat (7, s. 51-53). Z obsahu těchto tříd může být tedy voleno jako „příklad“ reprezentativní učivo či téma podle cíleně stanovených kriterií. Významná kriteria mohou vyplývat $\mathrm{z}$ analýzy pojmů technická gramotnost a technické myšlení a ze soudobých názorů na jejich dosahování či rozvíjení.

\section{Začlenění hodnocení techniky do výuky}

Technické myšlení, včetně jeho komponent jako je hodnocení a rozhodování, se vztahuje nejen k vytváření technických objektů, ale také k jejich užívání a údržbě i následným činnostem spojeným s likvidací odpadu (včetně dosloužilé techniky). Odborník i uživatel musí hodnotit možné alternativy řešení situací spojených s technikou až po odmítnutí činností. Tato řešení by tedy měli umět posoudit $\mathrm{z}$ hlediska širších a dlouhodobých souvislostí, možných dopadů a rizik $(8$, s. 93). Významné oblasti hodnocení konaného při technickém myšlení jsou cíl či účel, dále prostředky, postupy a způsoby dosažení cílů $\mathrm{v}$ daných podmínkách a s danými možnostmi a to vše s ohledem na důsledky či dopady dosahování cílů technikou. Technické myšlení i hodnocení se opírá o znalosti a dovednosti označované jako technické, ale také o znalosti a dovednosti př́rodovědné, společenskovědní a humanitní.

Hodnocení techniky a důsledků jejího užití je proto významnou součástí výuky „všech technických témat" bez ohledu na zaměření vzdělávání na všeobecné nebo odborné. Jako složka technického myšlení navazuje na „ک̌irší schopnosti“" kritického myšlení a rozhodování, viz (1, s. 22-33). Ve výuce technických předmětů nejčastěji probíhá realizace hodnocení uplatňovaného $v$ rámci nejrůznějších témat o technice. Lze se ale setkat i s tématy, kde je výuka zaměřena především na hodnocení techniky (přestože témata nejsou takto nazvána), jde o témata úzce související s ochranou životního prostředí a uchování přírodních zdrojů, o témata ekonomická stejně jako pracovně bezpečnostní, ergonomická atp.

Jako další východiska $\mathrm{k}$ začlenění hodnocení techniky do výuky lze podle úrovně výuky využít tyto odborné skutečnosti:

- Pro hodnocení zejména průmyslových postupů lze využít podklady, které jsou formulovány $\mathrm{v}$ rámci $\mathrm{EU}$ jako Referenční dokumenty o nejlepších dostupných technikách BREF (Reference Document on Best Available Techniques), jež jsou porovnávacími dokumenty používanými př́slušnými orgány členských států při vydávání př́slušných povolení, viz (9). Každý dokument BREF podává informace o príislušných kategoriích průmyslových činností (někdy by zde byl vhodnější termín technologie v názvech) v členských státech Evropské unie a obsahuje např. produkční charakteristiky, popis technik a používaných postupů, úroveň emisí, spotřeby surovin a energií. Ty musí schvalované technologie splňovat. Rozsáhlé texty dokumentů mohou být ovšem př́mo uplatněny jen $\mathrm{v}$ odborném vzdělávání vyšší úrovně, avšak již „filozofie“ těchto dokumentů je podnětná.

- V řadě států existují instituce zaměřené přímo na posuzování technických řešení, připravují rovněž podklady $\mathrm{k}$ optimalizaci politických rozhodnutí (8, s. 205), (10). Jejich „rámcové postupy“ lze transformovat i na „běžná hodnocení techniky a rozhodnutí o technice" a didakticky transformovat do výuky pro vytváření žákovy kompetence hodnotit techniku a dopady způsobu činnosti $\mathrm{s}$ technikou. Jde napríklad o využití rozhodovacích matic, extrapolace trendu, tvorby analogií s již vykonaným a jeho výsledky, brainstormingu, analýzy a klasifikace rizik a vlivů, poměru nákladů a užitku, ekologické bilance aj., viz (10).

- Ve výuce lze hodnocení techniky zahájit hodnocením vhodnosti cíle či účelu řešení. Následně musí každé technické řešení obstát řadě hodnotících aspektů či otázek, 
negativní odpověd' vede $\mathrm{k}$ zamítnutí nevhodného řešení. Podle (10) lze otázky přiřadit $\mathrm{k}$ těmto rámcovým oblastem, uvedené pořadí je účelné dodržet i ve výuce a může být aplikováno jak ve fázi vstupních řešení, tak při následné konkretizaci zpočátku neostř̌e vymezených řešení:

a - hodnocení technického řešení z hlediska prírodnich věd, zda je dostatečně popsáno, b - hodnocení z hlediska technické či technologické proveditelnosti,

c - hodnocení z hlediska ekonomické a ekologické proveditelnosti,

d - hodnocení z hlediska společenské, právní, politické, etické obhajitelnosti.

- Jako rámcová kriteria použitelná pro hodnocení techniky mohou být dle (10) využita hlediska: - funkčnosti, - bezpečnosti a stability funkce, - zdravotní nezávadnosti, - vztahu k životnímu prostředí, hospodárnosti, - efektivnosti, - možnosti rozvíjet osobnost. Konkretizace rámcových kriterií je nezbytná př́pad od případu.

- Při zvažování technických řešení v nejrůznějších situacích je uplatňována předběžná opatrnost vyplývající ze známé skutečnosti, že před zahájením řešení máme nejméně informací, ale největší možnosti volby variant. Během řešení stoupá informovanost o výsledcích i důsledcích řešení, ale možnost provádět změny se snižuje o náklady, které byly již vynaloženy.

\section{Hodnocení ve výuce o spalování komunálního odpadu}

V této části se blíže zaměříme na hodnocení směřované $\mathrm{k}$ jednomu ze způsobů nakládání s odpady, jímž je „průmyslové spalování“. Tuto technologii volíme, podobně jako $\mathrm{v}$ řadě jiných našich statí, pro „demonstraci“ aplikace pedagogické či didaktické teorie. Je to proto, že $\mathrm{v}$ této oblasti máme jisté odborné zázemí, pro inovativnost tématu, sepětí problematiky $\mathrm{s}$ běžným životem a nejvíce pro rozpornost, $\mathrm{s}$ jakou je technologie príiímána veřejností i odbornými kruhy. My se k potřebě spalování komunálního odpadu přikláníme, ale nikomu názor nevnucujeme a není to úkol učitele. Má je především naučit žáky získat informace, vytvořit si podložený názor, obhajovat jej a poctivě se jím řídit; když žák zjistí, že jeho názor není správný, měl by dokázat „podstoupit bolest jeho změny“.

Technologie spalování komunálního odpadu průmyslovým způsobem je jeden z možných způsobů tzv. nakládání s odpady, uplatněna je pouze po jejich vytř́iění pro vhodnější využití. Spalován tedy je ,jinak nevyužitelný zbytek odpadu“, do $25 \%$ objemu těchto odpadů (zbytku po vytrrídění), což u nás není nikde dosahováno ani $\mathrm{z}$ poloviny. Místo toho je prováděno především skládkování, povolené, ale v hierarchii nakládání s odpady hodnocené nejníže.

Spalovny komunálního odpadu slouží nejen pro zpracování odpadu (snížení objemu a hmotnosti pro ukládání na skládky, přeměna nebezpečných odpadních látek na látky neškodné; likvidací škodlivých látek se zde šíře nezabýváme), ale také jako významný zdroj tepla a elektrické energie. VEU jde o technologii uznávanou, je součástí zmíněných nejlepších dostupných technik BREF (9), u nás se „odpor“ některých institucí mění až v poslední době.

„Již zde“ mohou žáci začít získávat informace a hodnotit varianty skládkování nebo spalování komunálního odpadu. Vše uvedené je totiž z hlediska výuky podnětné. Rozpornost jako je tato vyvolává diskusi a přemýšlení o tématu $\mathrm{z}$ různých hledisek, hledání informací, uplatnění kritického myšlení, hodnocení, vytváření odlišných stanovisek mezi žáky a obhajobu stanovisek. Hodnocení spalování komunálního odpadu navíc zahrnuje rozsáhlé souvislosti prírodovědné i společenské (ekonomické, právní), které lze začlenit do výuky; víme, že studenty VŠ celá problematika odpadů zajímá.

K termínu odpad - podle zákona č.106/2005 Sb., o odpadech (11), je odpad „každá movitá věc, které se osoba zbavuje nebo má úmysl se jí zbavit a prrísluší do některé ze skupin odpadů uvedených v príloze č. $1 \mathrm{k}$ tomuto zákonu“" (§ 3 , odst. 1). Formulace „zbavit se“ může být využita k hodnotícímu posouzení se žáky. Kdo se chce odpadu zbavit? Vždyt' dnes jsou odpady shromažd'ovány, tříděny pro další zpracování s výstupy materiálovými a energetickými, nebo aby bylo možno zneškodnit jejich případné škodlivé účinky. Je tedy třeba rozlišit mezi původcem odpadu a zpracovatelem odpadu.

Důležitý je text § 4 uvedeného zákona, nazvaný „Další základní pojmy“. Přináší charakteristiky pojmů užívaných v souvislosti s odpady a nakládání s nimi, jde o pojmy významné i pro hodnocení problematiky.

Podle citovaného zákona rozlišujeme využívání odpadu (příloha č. 3 k zákonu) a odstraňování odpadů (př́loha č. $4 \mathrm{k}$ zákonu), souhrnně k nakládání s odpady. Povšimněme si tohoto pro výuku významného pojmu. Prioritu při nakládání s odpady má i dle uvedeného zákona minimalizace vzniku odpadů předcházením jejich 
vzniku, nebo úpravou použitých výrobků a materiálů pro jejich opětovné využití. Vznikl-li odpad, nebot' držitel se věci zbavuje, měl by být recyklován (zpracována na materiály nebo látky $\mathrm{k}$ původním nebo jiným účelům). Pokud toto nelze, měl by být materiál jinak využit (spalován, kompostován). Až následně přichází v úvahu odstraňování odpadu skládkováním. Zde je prostor pro hodnocení činností s technikou.

Lze očekávat, že ,„průmyslovým“ spalováním bude odpad zpracován rychle a s možností kontroly plynných i tuhých produktů spalování. Je tomu skutečně tak? Zařízení na energetické využívání komunálního odpadu vybavená systémy pro minimalizování emisí a zpracování zbytkových látek jsou ve světě ověřena. V ČR jsou tři spalovny komunálního odpadu v Praze, Brně a Liberci, viz jejich internetové stránky (12). Významněji jsou však tyto postupy využívány v zahraničí, např. ze sousedních zemí v SRN a v Rakousku - jen ve Vídni jsou tři spalovny komunálního odpadu a jedno velké centrum spalování průmyslového odpadu (13). Spalovny v ČR jsou zřetelně viditelné i na fotografiích obsažených $\mathrm{v}$ (14), lze je najít vyhledávačem podle adres uvedených v (12). Lze také ,z výšky vidět" alternativu spalování na Olomoucku - vytříděný komunální odpad je ukládán na skládkách severovýchodně od obce Mrsklesy (vložte do vyhledávače). Je možno vidět i stav v roce 2002/3. Žáci mohou, a rádi to dělají, získávat informace o spalovnách, mohou hodnotit i ,pravděpodobnost“", zda údaje těchto spaloven jsou pravdivé, zda by veřejná kontrola zde umožnila falšování údajů.

Pro hodnocení energetického př́nosu mohou být zváženy údaje spalovny komunálního odpadu v Praze-Malešicích - zařízení je schopno zvládnout většinu vytrríděného směsného komunálního odpadu vyprodukovaného na území Prahy, získaná energie je asi 1200 GJ/rok.

Hodnocení spalování komunálního odpadu z hlediska škodlivin, které mohou znečišt'ovat ovzduší, vyvolá diskusi. Skutečně vzniká velké množství škodlivin, ale současné systémy čištění spalin umožňují snížení emisí z procesu energetického využívání odpadu na úroveň emisí ze spalování zemního plynu, považovaného za „čisté palivo“ (15). Paradoxně, ale logicky, jsou nejpřísnější emisní limity legislativně stanoveny pro spalování odpadů. Jsou dodržovány a sledovány včetně obsahu těžkých kovů a dioxinů, které vznikají při jakémkoliv spalovacím procesu. (16). Při spalování ostatních paliv legislativa nevyžaduje sledování ani snižování množství těchto látek ve spalinách. Také logistické nároky nejsou odlišné od jiných způsobů zpracování odpadu.

Spalování komunálního odpadu není „nic nového“ - dle údajů internetových stránek SAKO Brno bylo v roce 1904 usnesením městského zastupitelstva v Brně rozhodnuto o budování městské spalovny odpadů, v roce 1905 vyrobila spalovna první elektrickou energii z odpadu. Byla to tehdy první spalovna Rakousko - Uherské monarchie, která využívala energetického potenciálu z odpadu k výrobě elektrické energie.

Legislativně je vČR spalování odpadu upraveno zejména nařízením vlády č.354 ze dne 3. července 2002, změněné nařízením vlády č. 206/2006 Sb. V dokumentu jsou stanoveny především emisní limity a další podmínky pro spalování odpadu.

Zbytek po spalování odpadu bývá využit především ve stavebnictví, dále je skládkován, ale objem i nebezpečnost zbytku je již nižší.

Menší možnosti hodnocení ve výuce vidíme, pokud jde o odstraňování nebezpečného odpadu (složení, původ, hygienické důvody). Zde vše podléhá potřebě jeho zneškodnění (ne využívání), které je prováděno neekonomickým spalováním za vysokých teplot $\left(>1100^{\circ} \mathrm{C}\right)$, zvyšovaných spoluspalováním zemního plynu.

Výzvou k hodnotícímu posouzení žáky jsou také některé souvislosti, které se týkají jejich běžného života. Jde například o ceny za odvoz komunálního odpadu a souvislost se vznikem divokých skládek, nevyužitím materiálového a energetického potenciálu a pochopitelně znečišt'ováním prrírody. Dalším námětem jsou převážně pozitivní trendy v praxi třídění komunálního odpadu. V těchto souvislostech je významná znalost toho, že popel $z$ běžného lokálního topeniště lze dále využít jako palivo v podmínkách průmyslového spalování.

\section{Závěrem}

Možnosti začlenění hodnocení do výuky jakožto požadavek komplexnosti výuky jsme ukázali na případu spalování komunálního odpadu. Je to téma s vysokým potenciálem k rozvíjení diskuse hodnotícího charakteru, k obhajobě názoru, k získávání dalších informací. Jde navíc o problematiku s mnoha př́rodovědnými a společenskými souvislostmi, čemuž jsme se pro nedostatek místa příliš nevěnovali, chceme proto alespoň upozornit na potřebu odstupu a zvážení věci z jakési vyšší či širší perspektivy. S tím vším hodnocení souvisí, proto je ve výuce nutné. 
Témat, které toto vše umožňují, je $\mathrm{v}$ technických předmětech nemálo. Lze je tvořivě využívat pro rozvíjení kritického myšlení a hodnocení. Účel i kriteria užití techniky leží nad technikou, ale hodnotící a kritické myšlení na ně navazuje. Technici i uživatelé techniky se významně podílejí na tom, zda ,instrumentální technické myšleni" bude využito $\mathrm{k}$ prospěchu člověka. Uvedená stránka výuky, hodnocení, směřuje k pozitivním cílům, jde o dobrý způsob dosahování vychovanosti a o spoluvytváření schopnosti hodnotit sám sebe.

\section{Literatura}

[1] KROPÁČ, J. a KROPÁČOVÁ, J. Didaktická transformace pro technické predměty. Olomouc: Univerzita Palackého, Pedagogická fakulta, 2006. ISBN 80-244-1431-7.

[2] BYČKOVSKÝ, P. a KOTÁSEK, J. Nová teorie klasifikování kognitivních cílů ve vzdělávání: Revize Bloomovy taxonomie. Pedagogika, 2004, roč. 54, s. 227-242. ISSN 0031-3815.

[3] KROPÁČ, J. a PLISCHKE, J. Integrace výsledků vzdělávání $\mathrm{v}$ obecně technických předmětech. In XXVII. mezinárodni kolokvium o rízení osvojovacího procesu : sborník abstraktů a elektronických verzí recenzovaných přispěvků na CD-ROMu [CD-ROM]. Brno: Univerzita obrany, 2009. ISBN 978-80-7231-650-2.

[4] KROPÁČ, J. st., KROPÁČ́, J. ml. a PLISCHKE, J. Komplexnost výsledků vzdělávání $\mathrm{v}$ obecně technických předmětech. Připraveno k publikaci - XXVIII. mezinárodní kolokvium o řízení osvojovacího procesu.

[5] WOLFFGRAMM, H. Allgemeine Technologie. Leipzig: VEB Fachbuchverlag, 1978.

[6] WOLFFGRAMM, H. Allgemeine Technologie. Band 1. Teil 1. Hildesheim: Verlag Franzbecker, 1994. ISBN 3-88120-241-2.

[7] FURMANEK, W. a WALAT, W. Przewodnik metodyczny dla nauczycieli technikiinformatyki. Rzeszów: Wydawnictwo Oświatowe FOSZE, 2002. ISBN 83-88845-08-X. [8] TONDL, L. Technologické myšleni a usuzování. Praha: Filosofia, 1998. ISBN 807007-105-2.
[9] Referenční dokumenty BREF [online]. [cit. 2010-02-22]. Dostupné na WWW: $<\mathrm{http}: / /$ www.ippc.cz/obsah/referencnidokumenty/>.

[10] BANSE, G. Technikfolgenabschätzung: Ein strategisches Rahmenkonzept mit politischem Anspruch. Unterricht - Arbeit + Technik, 2008, Jahrgang 10, Heft 39, Ss. 59-62. ISSN 14388987.

[11] Zákon č.106/2005 Sb., o odpadech [online]. [cit. 2010-02-24]. Dostupné na WWW: $<$ http://odpady.mesto-zatec.cz/prirucky/vsechnyprirucky.html>

[12] WWW stránky SAKO Brno jsou dostupné na http://www.sako.cz/informace/, WWW stránky ZEVO Praha jsou dostupné na http://www.psas.cz/, WWW stránky TERMIZO Liberec jsou dostupné na http://www.termizo.cz/ [13] HYŽÍK, J. Energetické využivání výhřevné frakce z MBÚ. Odpadové fórum, 2009, roč.10, č. 10, s. 11-12. ISSN 1212-7779.

[14] http://www.mapy.cz/

[15] HYŽÍK J. Energetické využívání odpadu je nepostradatelné. Odpady, 2008, roč. 18, č. 1, s. 21-22. ISSN 1210-4922.

[16] PEROUTKA, K. a SUZOVÁ, J. Znečišt'ující látky z energetického využití odpadů - fakta a mýty. Odpady, 2008, roč. 18, č. 4, s. 2022. ISSN 1210-4922.

Doc. PaedDr. Jiří Kropáč, CSc.

PhDr. Jitka Plischke, Ph.D.

Pedagogická fakulta UP

Žižkovo nám. 5

77140 Olomouc, ČR

Tel:. +420 585635805

e-mail: kropac@pdfnw.upol.cz,

jitka.plischke@upol.cz

Www pracoviště: www.kteiv.upol.cz

Ing. Jiří Kropáč (student DSP)

Fakulta strojního inženýrství VUT

Technická 2, 61669 Brno,

Tel: +420 541142 322,

e-mail: ykropa02@stud.fme.vutbr.cz

Www pracoviště:

http://www.upei.fme.vutbr.cz/cs/index 